\title{
Alternatives to groundwater abstraction as a measure to stop land subsidence: a case study of Semarang, Indonesia
}

\author{
Wesley van Beek ${ }^{1}$, Bart Letitre ${ }^{1}, H$. Hadiyanto ${ }^{2}$, and $S$. Sudarno ${ }^{3}$ \\ ${ }^{1}$ Environmental Science Department, Wageningen University, The Netherlands \\ ${ }^{2}$ Master Program of Envrionmental Sciences, School of Postgraduate Studies, Diponegoro University \\ ${ }^{3}$ Doctoral Program of Environmental Sciences, School of Postgraduate Studies, Diponegoro University
}

\begin{abstract}
The Water as Leverage project aims to lay a blueprint for urban coastal areas around the world that are facing a variety of water-related issues. The blueprint is based upon three real case studies in Bangladesh, India and Indonesia. The case of Indonesia focuses on Semarang, a city that faces issues like flooding, increased water demand, and a lack of wastewater treatment. In this report I summarise the different techniques available to tackling these issues. Along with this I provide a cost-benefit analysis to support decision makers. For a short term it is recommended to produce industrial water from (polluted) surface water as a means to offer an alternative to groundwater abstraction. On a long term it is recommended to install additional wastewater and drinking water treatment services to facilitate better hygiene and a higher quality of life.
\end{abstract}

Keywords: Land subsidence; polluted water; flooding.

\section{Introduction}

In order to prepare urban areas for a resilient future, the Netherlands Special Envoy for International Water Affairs initiated a programme called "Water as leverage" $(\mathrm{WaL})$. This programme aims to provide the necessary initial investments to incentivise the further implementation of real urban water resilience projects. WaL started pilots in three Asian cities with the prospect of laying a blueprint for other cities and regions around the world facing similar water challenges. One of these pilots is located in Semarang, Indonesia. Semarang deals with a combination of disasters, including floods, droughts, pollution and water conflicts [1]. In this report I look at the problems that Semarang is facing. Then, I review the general technical solutions to solve these issues. Finally, I compare these generic technical solutions to arrive at a recommendation.

Flooding is a big issue at the coast of Semarang causing a lot of damage to buildings and vehicles. In Semarang two types of flooding can be distinguished: pluvial floods and coastal floods. Different causes can be pointed out for the increasing threats of floods: a decrease in infiltration capacity in the highlands, more extreme rainfall patterns, and land subsidence below the sea. Land subsidence is the biggest contributor to the increasing flood risks in coastal areas of Semarang [2]. To counter these problems dams are constructed in the highlands to retain water for usage during the dry season. Closer to the coast land is protected using dikes and the polder system. However, the root cause for the increasing flood threats - land subsidence- has been neglected [3]. This problem is expected to worsen and cause high costs in the future. Therefore, immediate action to stop land subsidence is required.

The water demand in Semarang has grown from 0.5 million $\mathrm{m}^{3} /$ year in 1910 to 53 million $\mathrm{m}^{3} /$ year in 2000 due to the increase in population and industry [4]. The local water company (PDAM) has not been able to grow accordingly with the water demand of Semarang. Therefore, groundwater has increasingly become a resource for domestic users and industry in Semarang [5]. However, the abstraction of groundwater depletes aquifers below the ground. This in turn is a cause for land subsidence with subsidence rates in Semarang reaching up to $10 \mathrm{~cm} /$ year [6]. Land subsidence increases the risks to floods and landslides [7].

Only $1 \%$ of all wastewater in Indonesia is treated [8]. Despite attempts to manage waste effectively, central domestic waste water treatment and sewer systems are still lacking and should be improved [9]. Industrial waste water treatment is governed through the PROPER mechanism. However, in reality monitoring occurs only once every five years and is mostly a formality. Hence, there still lies a big challenge ahead to (liquid) waste management in Indonesia. The pollution in rivers and other water bodies make it challenging to use surface water as a water resource. Moreover, especially when highly polluted rivers cannot flow freely they may pose a threat to human health [10].

All of the three aforementioned problems require intervention both in technical and governmental means.

\footnotetext{
* Corresponding author: hadiyanto@live.undip.ac.id
} 
In this report I will focus in particular on the technical aspect. Moreover, I will only focus on the industrial areas Terboyo and Bugangan within the Genuk sub-district of Semarang. This area was selected because subsidence rates were among the highest in Semarang within the range of 8.5-10 cm/year in the period of 2008-2011 [6].
Also, the area suffers from poor governance resulting in little to no control with regards to pollution and groundwater abstraction. In order to counter land subsidence in this area, it is suggested to find an alternative to the current groundwater abstraction that amounts approximately $250 \mathrm{~L} / \mathrm{s}(\mathrm{WaL})$.

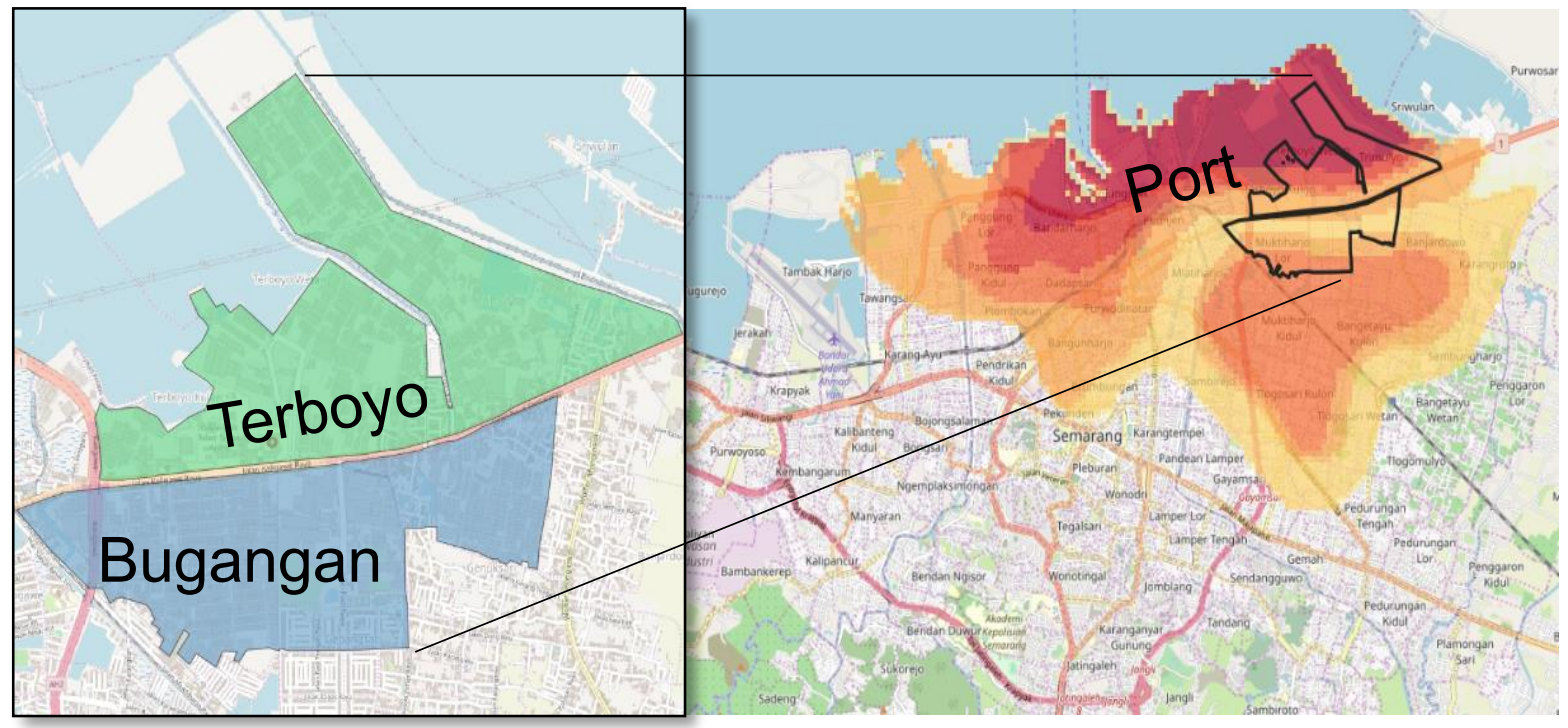

Fig. 1. Research location

\section{Technical Interventions}

Three main water resources can be distinguished: groundwater, seawater, and surface water. The current depletion of groundwater reservoirs make that this is not a possibility in the Genuk area. Secondly, seawater is not a feasible water resource to Genuk due to the high costs involved for both construction and operation \& maintenance. Hence, it appears that only surface water may be a feasible alternative to supply water to Genuk (see Table 1). Surface water can be further divided into rain water harvesting strategies and surface water reuse. Calculations have shown that it is not possible to supply $250 \mathrm{~L} / \mathrm{s}$ within Genuk from solely rain water harvesting. Some of the issues encountered include the lack of area for rainwater capture and storage, and high capital expenditures for the construction of sufficient storage capacity.

Table 1. Considerations for different water resources

\begin{tabular}{|l|l|l|}
\hline Technology & Advantages & Disadvantages \\
\hline Groundwater & $\begin{array}{l}\text { Few treatment steps required } \\
\text { No distribution network needed } \\
\text { No additional investment costs }\end{array}$ & $\begin{array}{l}\text { Aquifer depletion leading to land subsidence and } \\
\text { increased flood threats }\end{array}$ \\
\hline Seawater & Reliable water resource & $\begin{array}{l}\text { High CAPEX }(40-60 \mathrm{~m} \text { euros }) \\
\text { High OPEX }\left( \pm 20,000 \mathrm{IDR} / \mathrm{m}^{3}\right) \\
\text { Brine discharge \& } \mathrm{CO}_{2} \text { emissions threaten ecology }\end{array}$ \\
\hline Surface water & $\begin{array}{l}\text { Wastewater treatment benefits ecology } \\
\text { Medium CAPEX }( \pm 10 \mathrm{~m} \text { euros }) \\
\text { Medium OPEX }\left( \pm 10,000 \mathrm{IDR} / \mathrm{m}^{3}\right)\end{array}$ & water storage required \\
\hline
\end{tabular}




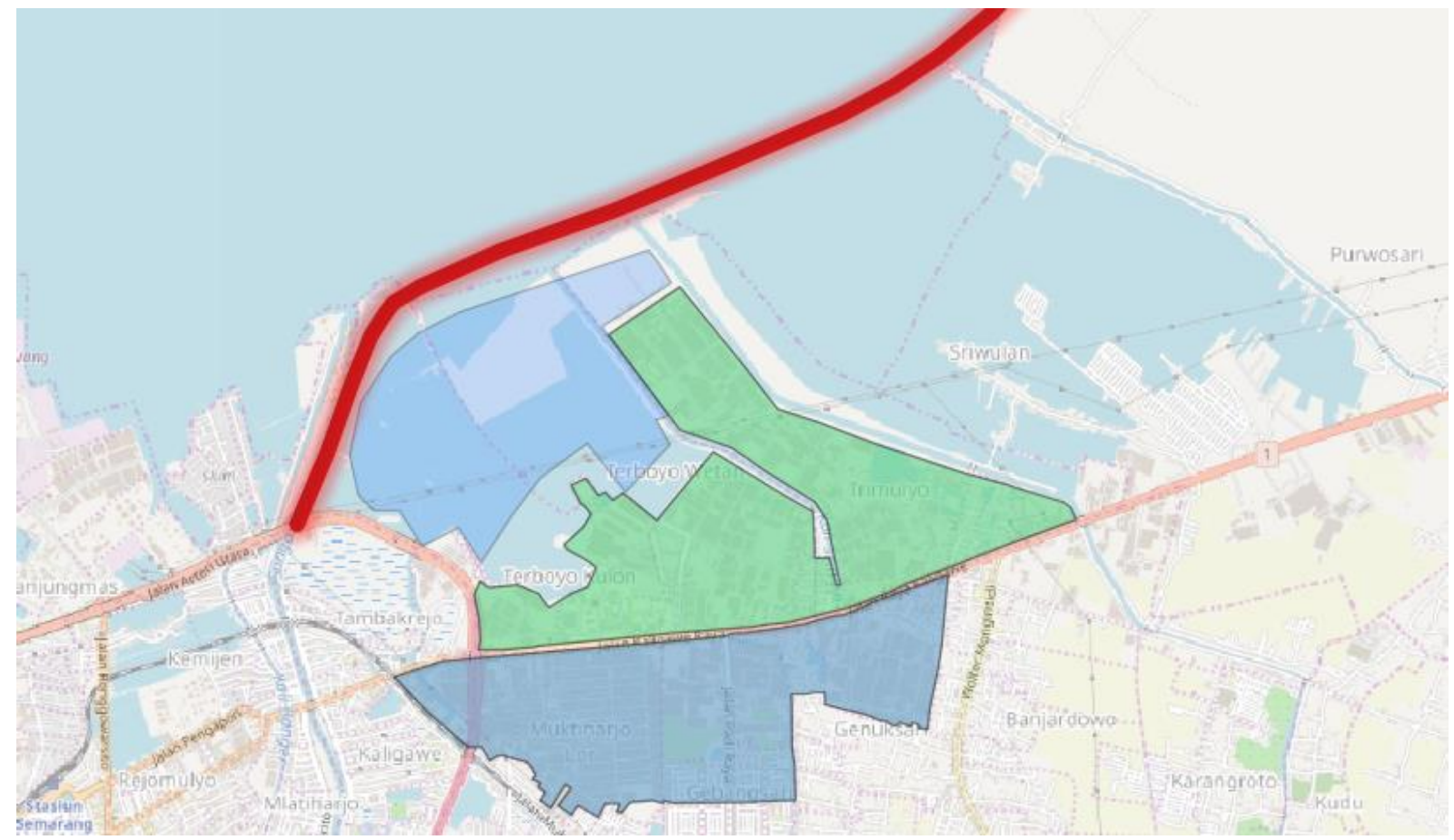

Fig. 2. Envisioned toll road from the port of Semarang to Demak is marked red

However, with the planned construction of a seawall ("sabok pantai") a reservoir of 225 ha emerges, giving possibility for an affordable water reservoir (see Figure 2 ). The reservoir receives water from the catchment area of the rivers Sringin and Tenggang. As these rivers are polluted by industry and domestic users, treatment is required. Furthermore, it is not known up to what extent industries directly discharge their (untreated) wastewater to the reservoir. Hence, this solution in fact is a combination of rain water harvesting and surface water reuse.

To arrive at the required water quality, different treatment steps are required. It is important to establish which water quality is demanded to provide adequate water supply. For instance, industries may prefer cheaper low quality water over expensive drinking water quality. In order to have an idea of the different water qualities around Genuk I analysed different water samples for the water quality. Note that I only consider in this report only TDS, nutrients and BOD/COD values. Further research is recommended with regards to the contamination by bacteria, viruses and anthropogenic micropollutants, i.e. industrial chemicals. An interpretation of the results for aforementioned parameters is shown in Figure 3 together with local legislation regarding water quality $[11,12]$.

\begin{tabular}{|l|c|c|}
\hline Legislation & $\begin{array}{c}\text { Sringin \& Tenggang after pumping } \\
\text { Industrial wastewater canals }\end{array}$ \\
\hline Based on TDS & & $\begin{array}{c}\text { Tenggang \& Sringin before pumping } \\
\text { Groundwater Kecap Kakap }\end{array}$ \\
\hline Based on nutrients & KWC IV & Most samples \\
\hline Based on COD & All samples \\
\hline
\end{tabular}

Fig. 3. Interpretation of water quality around Genuk area (see Appendix 1 for data)

From Figure 3, it becomes clear that all water samples were of raw water class (RWC) IV or lower based on the amount of COD, and are therefore not allowed to be used for drinking water production. TDS values in the envisioned reservoir were relatively high. This may be attributed due to the samples being close to turbulent areas, i.e. after a pumping station. The amount of TDS at a future intake may be lower due to sedimentation in the reservoir. Nutrient concentration of all samples that were taken directly from the envisioned reservoir were at least of RWC 1 and may thus be used for drinking water production.
For this reason it is required to first treat water up to a higher raw water quality to be allowed to produce drinking water, which is referred to as indirect potable reuse. However, using treatment steps that lower the amount of TDS it might be possible to produce industrial water, i.e. water that meets the same quality as the groundwater used by Kecap Kakap. In case that the objective is to produce drinking water quality, treatment should also decrease the amount of COD.

TDS removal technologies include sedimentation, flocculation, coagulation, and filtration. Assessing the water quality of the envisaged water intake point will 
reveal whether sedimentation in the reservoir suffices, or if additional treatment is required to reach a water quality required by industry. For the removal of COD, which is required to reach RWC 1, biological and physio-chemical removal technologies exist. Biological methods include constructed wetlands, (an-)aerobic digestion, and physiochemical separation. The considerations for these technologies are listed in Table 2.

Table 2. Considerations for COD treatment technologies

\begin{tabular}{|l|l|l|}
\hline Technology & Advantages & Disadvantages \\
\hline Constructed wetlands & $\begin{array}{l}\text { Positive ecolo } \\
\text { Low OPEX }\end{array}$ & $\begin{array}{l}\text { High required area } \\
\text { High CAPEX (dredging } \pm 25 \mathrm{~m} \text { euros) } \\
50-75 \mathrm{mg} / \mathrm{L} \text { residual COD }\end{array}$ \\
\hline (An-)aerobic digestion & $\begin{array}{l}\text { Small footprint } \\
\text { Biogas production (at COD }>1 \mathrm{~g} / \mathrm{L})\end{array}$ & $\begin{array}{l}50-75 \mathrm{mg} / \mathrm{L} \text { residual COD } \\
\text { High }\end{array}$ \\
\hline Physio-chemical separation & High COD removal efficiency & \\
\hline
\end{tabular}

\section{Recommendation}

The goal of this intervention is to present an alternative to groundwater abstraction. Therefore, I recommend to focus on a design that is capable of producing industrial water that is of higher quality than the currently used groundwater. In the long term the treatment may be adjusted to include more complete and advanced treatment to reach drinking water quality.

I recommend to start with a small intake near Terboyo Megah as this area is close to the water, the industrial management has a private water distribution network and appears more proactive than in Bugangan. The water intake should be located away from the land as to prevent against increased turbulence from waves that contribute to an increase in TDS. I suggest to install screens at the intake to prevent against floating plastics. Depending on the water quality obtained from this, I suggest a combination of flocculation and a trickling filter to improve the water quality up to RWC II. This will contribute to a reduction of COD, TDS and odour. Depending on the pollution by anthropogenic influences I recommend to add minimal disinfection treatment steps to reach a quality that is higher than the groundwater quality currently used.

In order to draft a more detailed design, it is recommended to conduct further research in the following areas:

- Direct wastewater discharge from industries to the reservoir, as this may bypass future wastewater treatment systems that operate before water enters the reservoir.

- Establish better target of the demand of water by industries in terms of quantity and quality.

- Assess anthropogenic pollution, i.e. industrial, agricultural, and personal care products.

- Discuss the usage of UASB reactors as a pre-treatment for the biggest polluters.

- Clarify and enforce rights and responsibilities by different management bodies to facilitate implementation of the new water supply.

\section{References}

1. W. Hadipuro, \& N. Y. Indriyanti, Typical urban water supply provision in developing countries : a case study of Semarang City, Indonesia, 11, 55-66 (2009)

2. Suripin et al., The Initial Step for Developing Sustainable Urban Drainage System in Semarang City-Indonesia, 171, 1486-1494 (2017)

3. Personal communication Pak Sudharto, Personal communication Pak Sudharto (UNDIP Semarang: faculty of Social and political sciences and graduate program on environmental studies) (2019)

4. D. Murdohardono, T. M. H. L. Tobing, \& A. Sayekti, Over pumping of ground water as one of causes of sea water inundation in Semarang City, Paper Presented at the International Symposium and Workshop on Current Problems in Groundwater Management and Related Water Resources Issues (2007)

5. D. Valentino, Kajian Pengawasan Pemanfaatan Sumberdaya Air Tanah di Kawasan Industri Kota Semarang, Jurnal Wilayah Dan Lingkungan, 1(3), 265 (2016)

6. H. Z. Abidin, H. Andreas, I. Gumilar, T. P. Sidiq, \& Y. Fukuda, Land subsidence in coastal city of Semarang (Indonesia): Characteristics, impacts and causes, Geomatics, Natural Hazards and Risk, 4(3), 226-240 (2013)

7. A. L. Nugraha, Hani'ah, \& R. D. Pratiwi, Assessment of multi hazards in Semarang city, AIP Conference Proceedings, 1857(1), 100006 (2017)

8. The World Bank, Indonesia Country study. (September) (2013)

9. S. M. Kerstens, M. Spiller, I. Leusbrock, I., \& G. Zeeman, Science of the Total Environment A new approach to nationwide sanitation planning for developing countries: Case study of Indonesia, Science of the Total Environment, , 550, 676-689 (2016)

10. I. N. Okeke, R. Laxminarayan, Z. A. Bhutta, A. G. Duse, P. Jenkins, T. F. O. Brien, \& A. Pablosmendez, Antimicrobial resistance in developing 
countries . Part I: recent trends and current status. 5(August), 481-493 (2005)

11. Kementerian Kesehatan, Peraturan Menteri Kesehatan Republik IndoKementerian Kesehatan (2010) Peraturan Menteri Kesehatan Republik Indonesia Nomor 492/Menkes/Per/IV/2010, Peraturan Mentri Kesehatan Republik Indonesia.nesia NOMOR 492/MENKES/PER/IV/2010. Peraturan Mentri Kesehatan Republik Indonesia, p. MENKES (2010)

12. Rebuplik Indonesia, Nomor 82 Tahun 2001: Pengelolaan kualitas air dan pengeldalian pencemaran air. 11 (2001). 